Article

\title{
The Interaction Effect between ESG and Green Innovation and Its Impact on Firm Value from the Perspective of Information Disclosure
}

\author{
Fen Zhang, Xiaonan Qin and Lina Liu * \\ Business School, Shandong Normal University, Jinan 250358, Shandong, China; maggy_123@163.com (F.Z.); \\ sdqinxn@126.com (X.Q.) \\ * Correspondence: karen_lina@163.com
}

Received: 7 January 2020; Accepted: 27 February 2020; Published: 2 March 2020

\begin{abstract}
Few studies have been conducted on whether the coexistence of green innovation and corporate social responsibility (CSR) has a favorable interaction effect on firm value. This interaction effect is of great significance for enterprises balancing resource allocation between two factors in the future. Meanwhile, information disclosure can reflect the efforts of enterprises in taking on CSR. Therefore, taking China's listed companies as an example, this paper studies the interaction effect of CSR after being divided into the three different dimensions of environment, society, and governance (ESG) and green innovation on firm value. The quantile regression method can reflect the impact of CSR and green innovation on the firm value of different levels. The study finds that: (1) green innovation can promote the improvement of medium- and high-level firm value; (2) only the disclosure of environmental and social information can have a positive impact on firm value; (3) the interaction effect between green innovation and social disclosure on firm value is a substitution effect, which will gradually weaken with the increase of firm value. This paper proposes that relevant departments should guide green funds into enterprises with capital constraints to alleviate the issue of fund crowding into CSR and green innovation.
\end{abstract}

Keywords: green innovation; ESG disclosure; social responsibility; firm value; quantile regression

\section{Introduction}

Green innovation has been evolving vertically and horizontally in every dimension, from the micro enterprise level to the macro national level, which has an important impact on the green development of enterprises of different countries around the world. However, market competition is fierce, and the pursuit of green innovation alone cannot meet the needs of multiple stakeholders. A growing number of enterprises have recognized the importance of social responsibility, and both social responsibility and green innovation are beneficial to the future sustainable development of enterprises [1]. Therefore, in reality, some enterprises not only carry out green innovation but take social responsibility into account as well, timely disclosing corporate social responsibility (CSR) information within the three dimensions of environment, society, and governance (ESG), all of which can send positive signals to all sectors of society. Therefore, in the case of the coexistence of green innovation and social responsibility, the question remains of whether they have an interaction effect on firm value. If so, are they complementary to each other and jointly promote the growth of firm value, or are they mutually substitutive and squeeze each other's capital investment?

Although many previous studies have found that general innovation and social responsibility have the interaction effect $[2,3]$ of complementing $[4,5]$ or replacing [6,7] firm value, there is still a lack of research on the interaction between green innovation and social responsibility on firm value. 
From the perspective of information disclosure, this paper examines the interaction effect of social responsibility, which is divided into the three dimensions of environment, society and governance, and green innovation on firm value. The study on the above issues will not only help enhance people's cognition of general innovation and social responsibility extension, but also help open up the black box of how green innovation and social responsibility jointly affect firm value.

Green and innovation have become the two most critical factors driving economic transformation in the countries dominated by industrial economy at this stage. However, the focus has been on the level of innovation in the past, making most Chinese enterprises to be at the innovative but not green stage of development [8]. Only by combining economic development and green development can we bring new growth points for sustainable economic development. Technological progress is one of the essential forces to promote green development, but the cost of technological progress always moving towards green is high [9]. How to vigorously promote green innovation and accelerate green transformation depends on whether green development can bring environmental benefits to enterprises while bringing economic benefits and enhancing firm value.

In order to show the endeavors that they make for undertaking social responsibilities to all walks of life, the enterprises of various countries disclose CSR information in environment, society and governance, and improve the transparency of CSR information disclosure [10]. From the economic point of view, social responsibility information disclosure needs to bear the cost. Why do enterprises prefer to pay for CSR information disclosure? Social responsibility information disclosure can reduce the risks of information asymmetry and adverse selection, which can not only reduce financing costs, but also improve the expected future earnings of enterprises [11-13]. On the other hand, it is not enough to only consider information disclosure, and it is also necessary to recognize that the dimensions of social responsibility are different [14], because even high levels of social responsibility may result in either enhanced or suppressed corporate reputation due to differences in dimensions [15]. At this time, stakeholders focusing on the wrong side may lead to inaccurate inferences. This study divided social responsibility into these three dimensions (i.e., environment, society, and governance) and examined the relationship between the information disclosure of these three dimensions and the firm value of enterprises.

As the world's largest developing country, China has introduced many economic policies that are conducive to sustainable development in recent years so as to transform the industrial economy into a sustainable economy [16]. Using China's listed companies between 2012 and 2018 as an example, this paper uses the approach of quantile regression to study the interaction effect among social responsibility information disclosure after being divided into the three different dimensions of environment, society, and governance, green innovation and firm value. The purpose of this study is that, first, it makes an in-depth study of social responsibility, dividing it into the three aspects of environment, society, and governance, and observes the impact of heterogeneous social responsibility information transparency on firm value. Second, from the perspective of information disclosure, it groups environment, society, and governance together with green innovation under a unified framework, discusses their interaction in terms of firm value, and deepens previous research on the interaction effect between general innovation and comprehensive social responsibility on firm value. Third, it adopts the OLS method to observe the influence of independent variables on the mean value of dependent variables. In this paper, the quantile regression method was used to investigate the influence of green innovation and ESG information disclosure on the overall distribution of firm value, which can better reflect the difference between the two factors in the different quantiles of firm value.

The structure of the rest of this paper is: Section 2 is Literature Review and Hypotheses; Section 3 is Research Design; Section 4 is Empirical Test and Result Analysis; Section 5 is Robustness Test; and Section 6 is Conclusion and Policy Recommendations. 


\section{Literature Review and Hypotheses}

\subsection{Green Innovation and Firm Value}

If China is to achieve high-quality development, green innovation and green development can help pave the way forward and have already received strong policy support. However, a key to enterprises, as an important support individual in macro-economic development, is whether they can coordinate macro strategies and micro strategies, since the ultimate goal of enterprises is to maximize economic benefits. No doubt, green development can bring environmental benefits, but whether it can bring economic benefits to enterprises has always been hotly debated in academia. Supporting opinions include the Porter-hypothesis [17] proposed by Porter and Wan der Linde (1995). According to this hypothesis, appropriate environmental supervision can improve the innovation ability of enterprises and then enhance their competitiveness. Although it may increase costs in the short-term, this supervision can improve business performance and promote economic development in the long-term. When studying the relationship between green entrepreneurial-oriented enterprises and their financial performance, Jiang et al. (2018) found that they not only play a significant role in promoting environmental performance but also significantly improved financial performance [18]. In their study on the relationship between green innovation and the corporate performance of Chinese listed companies between 2000 and 2010, Zhang et al. (2019) found that green innovation can improve the sales growth rate of enterprises, and the economic consequences of green innovation have been lagging behind for three years, which is a powerful verification of the strong Porter-hypothesis [1]. When Rezende et al. (2019) studied 356 multinational companies in Brazil, they found that the impact of green innovation on corporate financial performance was not evident within the same year but showed a significant positive impact in the following years [19]. However, Wang et al. (2019), using China's macro-level data from between 1990 and 2015, came to different conclusions. China has made significant progress in green innovation; however, based on the multi-production factor indicators following environmental adjustment, the development of China's economy still depends on factors like production capital rather than improvements in productivity [20]. Similarly, Stucki (2019) found in his study that only $19 \%$ of the companies with the highest energy cost inputs could receive a positive return on green innovation investment, while most companies do not necessarily receive a return [21].

There are many factors that could be behind the different conclusions from the existing literature: First, their research objects were different. The current capital market of China is unsound, its national conditions are complex, and it contains many types of enterprises, so the conclusions drawn from other countries may not be applicable to China's actual situation. Second, even if China was taken as the research object, the research conclusions drawn from earlier data may not have accurately reflected China's actual situation in recent years. For the past few years, the Chinese government has launched a series of policies to support the green development and transformation of enterprises. Based on the Porter-hypothesis and China's current policy orientation toward green innovation, this paper studies the impact of the green innovation of Chinese enterprises on their firm value, and puts forward the following hypotheses about this issue:

Hypothesis 1 (H1). Green Innovation Has A Positive Impact on Firm Value.

\subsection{ESG Information Disclosure and Firm Value}

The three major sectors of the environment, society and governance, as an essential part of social responsibility report, have received increasing attention from enterprises of various countries and their stakeholders, which helps develop sustainable strategies that affect the enterprises' future development [22]. In recent years, Chinese government departments and other regulatory agencies also issued a number of documents to support this. In 2018, the Guidelines for Environmental, Social and Corporate Governance Information Disclosure of Listed Companies of Shanghai Stock Exchange 
entered the stage of consultation. In October of the same year, Shenzhen Stock Exchange drafted ESG Information Disclosure Guidelines and held three consultation forums. In 2018, CSRC issued the newly revised Code of Corporate Governance for Listed Companies. One of the revised contents is that China should draw on international experience and basically establish the basic framework of environmental, social responsibility and corporate governance information disclosure. The Hong Kong Stock Exchange issued a consultation paper on the review of the Environmental, Social and Governance Reporting Guidelines (ESG Guidelines for short) and the relevant listing rules in May 2019 to further strengthen the requirements of ESG information disclosure.

To overcome pressure from the accountability system of relevant departments, not merely Chinese enterprises, the enterprises around the world not only make traditional financial reports, but also disclose their non-financial information to the stakeholders by improving the disclosure transparency of ESG information in the social responsibility report [23]. This behavior can be explained by the signal theory [24]. Improving the degree of ESG information disclosure can not only reduce the risks of information asymmetry and adverse selection but also showcase the efforts of enterprises in social responsibility and provide valuable information for stakeholders to help them make accurate decisions. On the other hand, due to the good reputation of operation, capital can be obtained at low costs [25,26], which, in terms of enterprises, can be introduced into their production departments, improve their efficiency, and, thus, achieve the purpose of improving their value. Yu et al. (2018) also found that, by studying the relationship between ESG transparency and firm value in 49 countries, for most listed companies, the benefits of ESG information disclosure are greater than the costs [27]. However, some scholars hold the opposite view. Friedman (1970) argued that, only when an enterprise maximizes its benefits, does it realize it social responsibility [28]. Duque-Grisales (2019) found that investment in ESG activities will increase the costs for enterprises, and ESG scores are significantly negatively correlated with the financial performance of enterprises [29]. There are also scholars who reached irrelevant conclusions on this matter [30].

From the above analysis, it can be seen that the true relationship between the degree and type of CSR and corporate performance has not yet been determined. In the past, analyses only used the total score of ESG as a basis to study the relationship between social responsibility information disclosure and firm value, but social responsibility is composed of three dimensions: environment, society, and governance. It is currently unknown whether there are differences among these three factors in terms of their impact on firm value. Brammer et al. (2006) found that due to the differences in dimensions, even high-level disclosure of social responsibility may be inconducive to the impact on firm value, because different types of ESGs reflect different operating motivations of enterprises, so their impact on stock returns is different [15]. At this time, business managers' focus on the wrong aspects may lead to inaccurate inferences. From the perspective of stakeholder theory, studying the different dimensions of ESG is important to firm value. With the global attention to ESG, Orens et al. (2010) found that the ESG dimension is related to the expected growth rate of the company's cash flow. This shows that the disclosure of ESG information in different dimensions by the company has an important impact on the future cash flow growth of firm value [31]. Qiu et al. (2016) found that the information disclosure of only two dimensions, E and S, could drive the increase of market value [32]. Qiu et al. (2019) also found that environment, society, and governance have different impacts on these financing costs; only the dimensions of environment and governance can ultimately reduce them [33]. When they studied the relationship between ESG's three-dimension disclosure scores and ROA, Brogi et al. (2019) found that all three dimensions were positively correlated with ROA, but $S$ was the most correlated with ROA [34]. Based on this, this study discusses the relationship between firm value and the three dimensions of environment, society, and governance and discusses whether the information disclosure of each dimension has a consistent or positive impact on firm value. This study attempts to verify this relationship. Based on this, we propose the following hypotheses:

Hypothesis 2a (H2a). The Information Disclosure in the Dimension of Environment in CSR Has A Positive Impact on Firm Value. 
Hypothesis $\mathbf{2 b} \mathbf{( H 2 b )}$. The Information Disclosure in the Dimension of Society in CSR Has A Positive Impact on Firm Value.

Hypothesis 2c (H2c). The Information Disclosure in the Dimension of Governance in CSR Has A Positive Impact on Firm Value.

\subsection{Interaction Effect of Green Innovation and ESG on Firm Value from The Perspective of Information Disclosure}

It can be seen from the above analysis that green innovation, the active fulfillment of social responsibility, and the timely disclosure of relevant information will have an impact on firm value, but whether the coexistence of the two will have a common impact on firm value is the main issue discussed in this section. By assessing the relevant literature, we found that existing research is more focused on the impact of general innovation and social responsibility on firm value. Therefore, before discussing the relationship between green innovation and social responsibility information disclosure, we will review previous research on the interaction between general innovation and social responsibility and its impact on firm value.

Some scholars argue that the interaction between these two factors may take on a complementary effect. According to Mcwilliams and Siegel (2000), CSR and innovation do not conflict with each other, and they should instead form complementary strategic decisions to jointly promote the enhancement of firm value [5]. Similarly, Carrasco and Buendía (2013) found that, when social responsibility is transformed into corporate culture, it can promote enterprises to innovate and create value [4]. However, some hold the opposite view: when social responsibility and innovation coexist, they can occupy each other's capital investment, and their mutual influence on firm value takes on the substitution effect. This view has been confirmed by some scholars. If an enterprise invests too much money in social responsibility activities, its consumers will think that the enterprise overuses scientific research funds, that the product quality is not guaranteed, or that the enterprise's performance will be reduced [7,35]. Similarly, Coluccia et al. (2019) found that there is a substitution effect occurring between investment in R\&D and ESG scores. Investment in R\&D can improve enterprise performance, while the ESG score has no significant impact on enterprise performance, so enterprises should disclose a greater amount of relevant $R \& D$ information to stakeholders [6].

In assessing the above literature, it can be found that the impact of general innovation and social responsibility on firm value is more likely to take on a substitution effect. Similarly, as an extension of general innovation, green innovation is not only different but also related. Moreover, general innovation may produce "dirty technology", which will temporarily improve the operating income of the enterprise but is not conducive to its long-term development. Like general innovation, green innovation will incur costs during the research and development process, but often brings higher costs. For this reason, the impact of green innovation and social responsibility on firm value is more likely to take on a substitution effect.

Stakeholder theory can be used to explain its mechanism of potential impact. ESG disclosure can reflect the efforts of enterprises in ESG performance. Therefore, when a company makes a decision, whether it is to improve its green innovation ability or to display its ESG performance through the information disclosed in the social responsibility report, its purpose is to increase the value of the company. However, it cannot be ignored that the internal resources of enterprises are limited, both of which will increase the direct cost of enterprises. The ratio between the costs borne and the benefits gained is the essence of the change of enterprise performance. If the input cost is high and the increased benefits are relatively low, it will have a negative impact on firm value in essence. Furthermore, compared with the direct promotion effect of green innovation on enterprise development, the impact of ESG on enterprises is more indirect and complicated, and it is mainly achieved by satisfying other stakeholders such as government and the public. There are often inconsistencies or even conflicts among stakeholders, and the impact of green innovation and ESG on firm value may be offset or 
replaced to some extent. Therefore, the interaction effect between socially responsible behavior and investment in scientific and technological innovation on enterprises is a substitution effect. On the other hand, ESG is composed of the three dimensions, and the execution cost of each dimension is different [36]. Therefore, it is necessary to discuss the impact of green innovation and ESG on firm value. Based on this, this paper proposes the following hypotheses:

Hypothesis 3a (H3a). The Interaction Effect of Environmental Information Disclosure and Green Innovation on Firm Value in CSR is A Substitution Effect.

Hypothesis $\mathbf{3 b} \mathbf{b}(\mathbf{H} \mathbf{3} \mathbf{b})$. The Interaction Effect of Social Information Disclosure and Green Innovation on Firm Value in CSR is A Substitution Effect.

Hypothesis 3c (H3c). The Interaction Effect of Information Disclosure and Green Innovation on Firm Value in CSR is A Substitution Effect.

\section{Research Design}

\subsection{Sample Selection and Data Sources}

To promote the development of a green economy and improve environmental and social performance, the former China Banking Regulatory Commission published the Green Credit Guidelines in February 2012. Therefore, this paper takes 2012 as its starting year and takes A-share non-financial companies listed on Shanghai and Shenzhen Stock Exchanges between 2012 and 2018 as samples. According to the demands of the study, the samples were selected as follows: (1) enterprises marked with ST and *ST were removed, since the financial performance of the enterprises in financial distress may be significantly different from that of other enterprises; (2) samples with missing major variables were removed; and (3) samples with missing control variables were removed. After this sorting, the final sample contained seven-year information on 952 listed companies with a total of 5764 observed values. Among all the variables involved in the measurement, the data on the major variables of green innovation as well as the environment, society, and governance, information disclosure scores were obtained from the China National Intellectual Property Administration (CNIPA) and the Bloomberg Database. The rest of the data came from the Wind Info Database and the CSMAR Database.

\subsection{Variable Selection}

The major variables used in this study were firm value, green innovation, and ESG information disclosure, which will be defined in the following sections.

\subsubsection{Firm Value}

We used Tobin's $Q$ as a dependent variable to measure firm value $[37,38]$. Tobin's $Q$ is widely used in relevant research on firm value $[27,30,39]$. This indicator does not only reflect the current company's profitability but also reflects its future development potential. The specific calculation method uses the market value divided by the total assets minus the net amount of intangible assets and the value of goodwill.

\subsubsection{Green Innovation}

Presently, there is no universally accepted definition of green innovation [40], but, for general purposes, green innovation is directly related to environmental performance and technological progress [41]. Therefore, the green innovation mentioned in this paper refers to the green technology innovation that can prevent and control environmental pollution, achieve the purpose of energy conservation and emission reduction, and be conducive to the green technology innovation promoting the ecological balance of natural resources. Green innovation input is difficult to separate from each company's report and does not necessarily bring output after input, while as the output of green 
innovation, the number of green patent applications in the current year is likely to show an impact on firm value, so this study used the number of applications of green patents in the current year as a proxy variable for green innovation. For the steps of green patent obtainment, please refer to the practice of Zhang et al. (2019) [1]. First, the patent identification numbers of the year of application of each company were collected manually from the patent retrieval website of CNIPA, and then the final data was obtained via data cleaning and screening with regard to the green technology patent classification number defined by the World Intellectual Property Organization (WIPO).

\subsubsection{Environment, Society and Governance Disclosure}

In this study, we focused on studying the information disclosure level of social responsibility in terms of three terms: environment (E), society (S), and governance (G). After a comprehensive investigation, Bloomberg can provide the data needed for this study. The purpose of the ESG information disclosure scores from Bloomberg was to measure the amount of disclosure of the ESG data included in corporate public reports (i.e., ESG transparency) rather than its actual performance [27]. The score is based on the degree of information disclosure for the three aspects, with scores ranging from 0.1 to 100; that is, the more data that is disclosed, the higher the score, level of information disclosure, and transparency. These scores represent the achievements of enterprises in undertaking social responsibility to all walks of life [10], passing more non-financial information to stakeholders to help them make decisions. Besides, each data point is scored according to its importance. For example, the disclosure of emissions from polluting gases is scored higher than other information. Moreover, Bloomberg can adjust scores according to different industries to distinguish industry differences.

\subsubsection{Control Variables}

To eliminate bias caused by the unobservable heterogeneity of enterprises, a series of control variables were added to ensure the accuracy of the results. Representing the profitability of enterprises with return on equity (roe); representing the short-term solvency of enterprises with a liquidity ratio (lr); representing the leverage ratio of enterprises with an asset-liability ratio (lev) and cash asset ratio (flow) [6,10,29]; representing the equity concentration of enterprises with ten major equity concentration ratios (topten), and observing and studying the internal decision-making level of enterprises [27]. Besides, considering that enterprise scale, age, and nature will affect the firm value [18,27], representing the enterprise scale with the logarithm of enterprise assets (size), and representing the business period (age) with the result of the years minus the date of establishment. Representing the corporate nature of enterprises (stateown) with the virtual variables set [1], 1 for state-owned enterprises and 0 for non-state-owned enterprises. Finally, for companies in different industries, the three dimensions score differently. To eliminate this effect, this paper controlled the industry level in accordance with the latest edition of the Guidelines for the Classification of Listed Companies in China. See Table 1 for the definition and description of the specific variables.

Table 1. Selection and description of related variables.

\begin{tabular}{|c|c|c|}
\hline Symbol & Variables & Variable Definitions \\
\hline TobinQ & Firm Value & $\begin{array}{l}\text { Tobin's } \mathrm{Q}=\text { (market value)/ } \\
\text { (total assets-Net balance of intangible assets-goodwill) }\end{array}$ \\
\hline GI & Green Innovation & Green patent applications \\
\hline E_dis & Environmental Information Disclosure in CSR & Environmental disclosure score in Bloomberg \\
\hline S_dis & $\begin{array}{c}\text { Social } \\
\text { Information Disclosure in CSR }\end{array}$ & Social disclosure score in Bloomberg \\
\hline G_dis & Governance Information Disclosure in CSR & Governance disclosure score in Bloomberg \\
\hline roe & Return On Equity & $\mathrm{ROE}=($ net profit $) /($ average owner's equity) \\
\hline $\operatorname{lr}$ & Liquidity Ratio & Liquidity Ratio $=$ (current assets) $/$ (current liabilities) \\
\hline lev & Asset-Liability Ratio & Asset-Liability Ratio = (total liabilities $) /($ Average total assets $)$ \\
\hline flow & Cash Asset Ratio & Cash Asset Ratio = (cash and cash equivalents + trading financial assets $) /($ total assets $)$ \\
\hline topten & Top Ten Holders Rate & The sum of the shareholding ratio of the top ten shareholders \\
\hline size & Firm Size & Firm Size $=$ Log (total assets) \\
\hline age & Firm Age & The business period with the result of the years minus the date of establishment. \\
\hline stateown & State-Owned Enterprises & Dummy variable, 1 for state-owned enterprises and 0 for non-state-owned enterprises. \\
\hline
\end{tabular}




\subsection{Methodology and Model Setting}

\subsubsection{Panel Quantile Regression}

Quantile regression was first proposed by Bassett and Koenker [42] to describe the whole picture of the relationship between explanatory variables at different points in the conditional distribution of the explained variables. The results of this method are considered to be more robust than those of classical OLS regression. As the traditional OLS regression method needs to meet a variety of assumptions prior to running, the random disturbance term should have a mean of zero and be identically distributed if the error term meets the normal distribution condition. In the actual economic situation, however, it is found that most economic indicator data does not meet the above assumptions [43]. Quantile regression can better observe the overall distribution of data without data processing, making up for some of the defects of OLS regression [44]. The reasons for using quantile regression method in this study can be summarized as follows: First, the method provides more accurate and reliable results in the presence of outliers and heavy-tailed distribution, and second, the quantile regression method does not consider any distribution assumption, and the data take on an asymmetric distribution [45].

The standard form of the panel quantile model is Formula (1):

$$
Q_{\theta}\left(y_{i} \mid x_{i}\right)=x_{i} \alpha_{\theta}+\mu_{\theta}
$$

where $y$ represents an endogenous variable, $x$ represents an exogenous variable, $0<\theta<1$ represents the proportion of values less than the $\theta$ th quantile.

\subsubsection{Basic Model Setting}

Based on the previous analysis, the model was constructed in two steps by drawing on the experience of models built by predecessors Zhang (2019) [1] and Brogi (2019) [45].

The first step built a single relationship model of the impact of corporate green innovation and ESG information disclosure on firm value according to hypotheses $\mathrm{H} 1$ and $\mathrm{H} 2$. The specific model is shown as Formulas (2) and (3):

$$
\begin{gathered}
Q_{\tau}(\text { Tobin } Q)=\beta_{0 \tau}+\beta_{1 \tau} \mathrm{GI}+\sum \beta_{i \tau} \text { Controls }+ \text { Industry }+\varepsilon_{\tau} \\
Q_{\tau}(\text { Tobin } Q)=\gamma_{0 \tau}+\gamma_{1 \tau} E_{d i s}+\gamma_{2 \tau} S_{d i s}+\gamma_{3 \tau} G \_d i s+\sum \gamma_{i \tau} \text { Controls }+ \text { Industry }+\delta_{\tau}
\end{gathered}
$$

The second step built a research model of the mutual influence of green innovation and ESG information disclosure on firm value according to the hypothesis H3. The specific model is shown as Formula (4):

$$
\begin{aligned}
Q_{\tau}(\text { Tobin } Q)=\lambda_{0 \tau}+ & \lambda_{1 \tau} G I+\lambda_{2 \tau} E_{d i s}+\lambda_{3 \tau} S_{d i s}+\lambda_{4 \tau} G_{d i s}+\lambda_{5 \tau} G I \times E_{d i s}+\lambda_{6 \tau} G I \times S_{d i s} \\
& +\lambda_{7 \tau} G I \times G_{d i s} \sum \lambda_{i \tau} \text { Controls }+ \text { Industry }+\rho_{\tau}
\end{aligned}
$$

Among them, the three items, GI $\times E \_d i s, G I \times S \_d i s$, and $G I \times G \_d i s$ in Model (4) are interaction items, which were used to test the interactive impact of green innovation and the information disclosure level of the three aspects of ESG on firm value.

\section{Empirical Test and Result Analysis}

\subsection{Descriptive Statistics}

Table 2 presents the descriptive statistic results for the variables. It can be seen that the average value of green innovation is 4.745 , the standard deviation is 32.26 , and the minimum value and maximum value greatly differ, indicating that the green innovation of Chinese listed enterprises is much different. In the three dimensions of social responsibility information disclosure, it can be seen 
that ESG's information disclosure scores are different. Among these, the environmental information disclosure score is the lowest, with an average value of 10.414 , and the highest is governance information disclosure, followed by social information disclosure. On the other hand, it reflects that the length of ESG information disclosure was different in the social responsibility reports published by enterprises, and the disclosure level of each indicator was different as well, which provided a basis for this paper to study the impact of different levels of social responsibility information disclosure on firm value.

Table 2. Descriptive statistical results of variables.

\begin{tabular}{cccccc}
\hline Variable & $\mathbf{N}$ & Mean & Std. Dev. & Min & Max \\
\hline TobinQ & 5764 & 2.320 & 1.894 & 0.737 & 31.393 \\
GI & 5764 & 4.745 & 32.26 & 0 & 966 \\
E_dis & 5764 & 10.414 & 6.448 & 1.55 & 53.125 \\
S_dis & 5764 & 25.182 & 8.62 & 3.509 & 73.684 \\
G_dis & 5764 & 44.882 & 5.484 & 5.357 & 62.5 \\
roe & 5764 & 0.045 & 0.065 & -0.775 & 0.598 \\
lr & 5764 & 1.977 & 3.075 & 0.079 & 104.667 \\
lev & 5764 & 0.487 & 0.199 & 0.008 & 1.352 \\
flow & 5764 & 0.143 & 0.109 & 0.001 & 0.798 \\
topten & 5764 & 59.932 & 16.17 & 9.164 & 98.588 \\
size & 5764 & 23.162 & 1.364 & 19.541 & 28.520 \\
age & 5764 & 18.546 & 5.382 & 3.000 & 40.000 \\
stateown & 5764 & 0.539 & 0.499 & 0 & 1 \\
\hline
\end{tabular}

To avoid multiple collinearity in regression analysis, moreover, the correlation coefficient test (as shown in Table A1) and the variance inflation factor (VIF) test between variables were conducted. As can be seen from Table A1, the correlation coefficient between E_dis and S_dis is 0.522, the correlation coefficient between E_dis and G_dis is 0.337 , the correlation coefficient between S_dis and G_dis is 0.350. The correlation coefficients among the three dimensions of ESG are high. However, the correlation coefficient can only measure the correlation between two variables. Since there may be more than two control variables in the regression, the VIF test for regression between the variables may be more practical than the correlation coefficient [34]. Therefore, this paper also has done a VIF test. The highest VIF obtained by the regression is 2.24 (less than 3). This result ensures that we stay away from concerns about multi-collinearity and confirms the reliability of the regression analysis.

Besides, before the empirical test, this paper conducted the SW Test (Shapiro-Wilk test) for the major variables to test the normal distribution. The results showed that the $P$ value was less than 0.05 , which meant a rejection of the original hypothesis, indicating that the variables did not obey the normal distribution. The quantile $\mathrm{Q}-\mathrm{Q}$ normality test chart also shows that the variable distribution did not obey the normal distribution, as shown in Figure 1. In addition, the skewness and kurtosis of the major variables were tested in this paper, which also proved that the distribution of variables was asymmetric. All of the above results indicate that there may have been estimation bias in the use of the OLS regression, so this paper used the quantile regression method for its empirical test in order to overcome the shortcomings of OLS. 


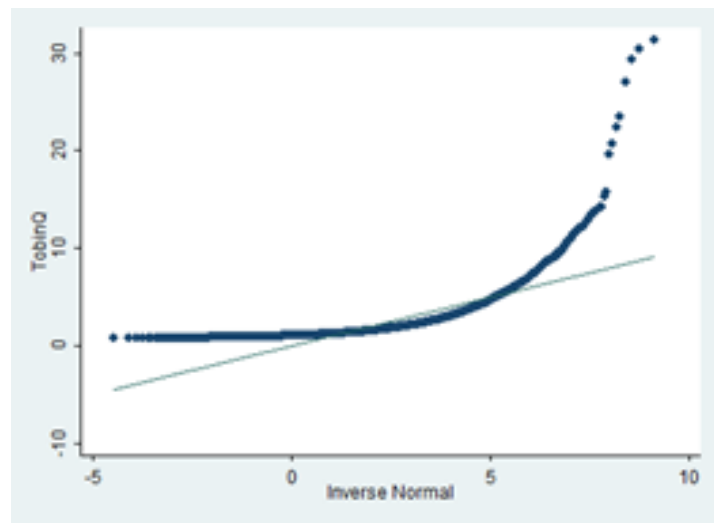

(a)

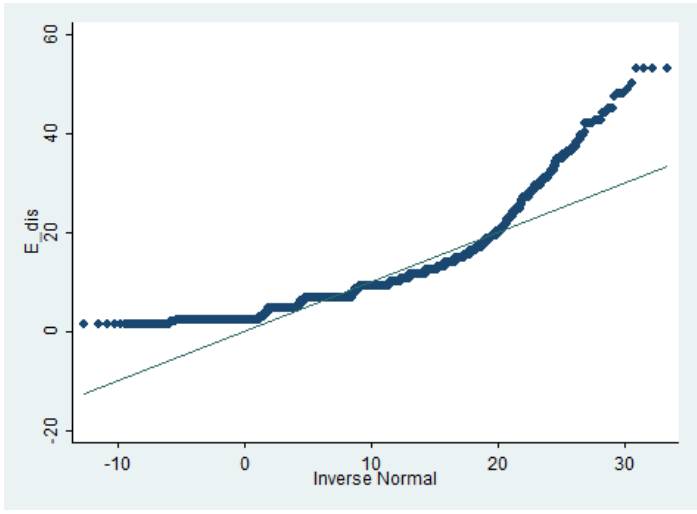

(c)

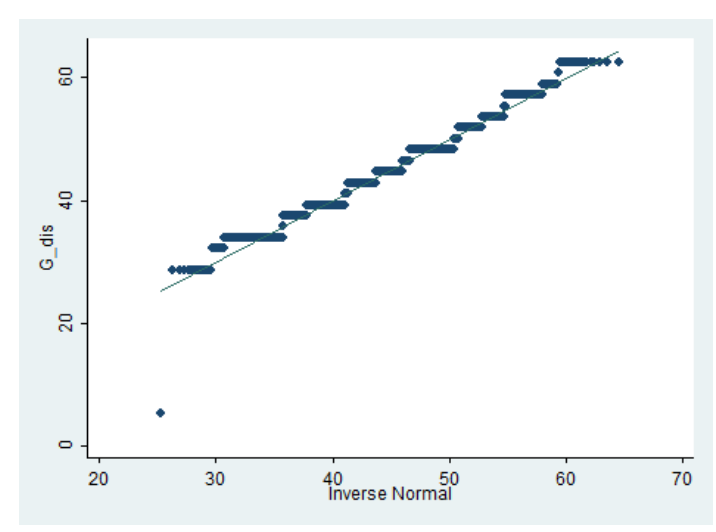

(e)

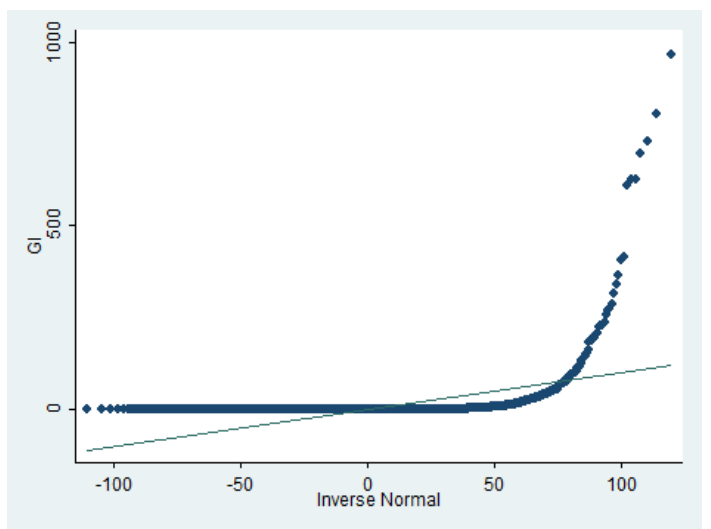

(b)

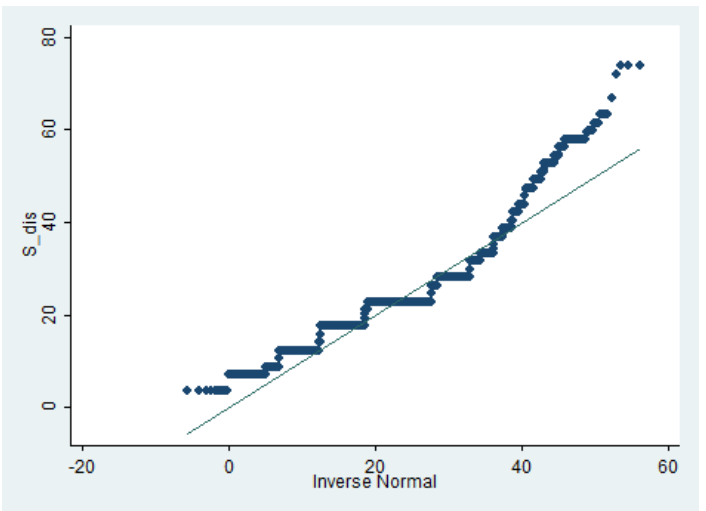

(d)

- 


\subsubsection{Test of Green Innovation and Firm Value}

A regression analysis was conducted on the relationship between green innovation and firm value according to the research hypothesis H1; that is, a regression test was conducted based on Model (2). The results are shown in Table 3. Both the OLS and quantile methods show that the coefficient of green innovation to firm value was significantly positive, indicating that green innovation has a significant role in promoting firm value, which strongly supports the research hypothesis H1. The overall change is seen by quantile regression. The regression coefficient of green innovation to firm value first increased in the range of 10th quantile to 50th quantile, and the coefficient remained stable in the subsequent high quantile. This showed that the positive effect of increasing green innovation on the value of medium- and high-level enterprises is greater than that of low-level enterprises; that is, improvements in the level of green innovation can better promote the growth of firm value. This result also provided empirical support for the Porter-hypothesis [16].

Table 3. Regression results of green innovation and firm value.

\begin{tabular}{|c|c|c|c|c|c|c|}
\hline \multirow{2}{*}{ Variables } & \multirow{2}{*}{ OLS } & \multicolumn{5}{|c|}{ Quantile Levels } \\
\hline & & 10th & 30th & 50th & 70th & 90th \\
\hline GI & $\begin{array}{c}0.0014^{* * *} \\
(5.96)\end{array}$ & $\begin{array}{c}0.0006^{* * *} \\
(6.56)\end{array}$ & $\begin{array}{c}0.0009 * * \\
(2.70)\end{array}$ & $\begin{array}{c}0.0010^{* * *} \\
(3.92)\end{array}$ & $\begin{array}{c}0.0010 * \\
(2.13)\end{array}$ & $\begin{array}{c}0.0010 * \\
(2.25)\end{array}$ \\
\hline roe & $\begin{array}{c}-0.8756^{* *} \\
(-2.45)\end{array}$ & $\begin{array}{c}-0.3465 \\
(-1.64)\end{array}$ & $\begin{array}{c}-0.4786^{*} \\
(-2.20)\end{array}$ & $\begin{array}{c}-1.2456^{* *} \\
(-2.68)\end{array}$ & $\begin{array}{c}-1.3695 * * * \\
(-4.82)\end{array}$ & $\begin{array}{c}-1.7481 * \\
(-2.43)\end{array}$ \\
\hline $\operatorname{lr}$ & $\begin{array}{c}0.0457^{*} \\
(2.34)\end{array}$ & $\begin{array}{c}0.0153 \\
(1.54)\end{array}$ & $\begin{array}{c}0.0264 \\
(1.32)\end{array}$ & $\begin{array}{c}0.0823^{* * *} \\
(3.74)\end{array}$ & $\begin{array}{c}0.1311^{* * * *} \\
(4.20)\end{array}$ & $\begin{array}{c}0.1945^{* * *} \\
(4.63)\end{array}$ \\
\hline lev & $\begin{array}{c}-0.6232 \text { ** } \\
(-2.95)\end{array}$ & $\begin{array}{c}0.0623 \\
(-1.60)\end{array}$ & $\begin{array}{c}-0.1866 \text { * } \\
(-2.14)\end{array}$ & $\begin{array}{c}-0.3143^{* * *} \\
(-3.69)\end{array}$ & $\begin{array}{c}-0.7536^{* * *} \\
(-4.37)\end{array}$ & $\begin{array}{c}-1.0031^{* * *} \\
(-4.10)\end{array}$ \\
\hline flow & $\begin{array}{c}1.5610^{* * *} \\
(4.36)\end{array}$ & $\begin{array}{c}0.4637^{* * * *} \\
(5.32)\end{array}$ & $\begin{array}{c}0.6665^{* * * *} \\
(4.34)\end{array}$ & $\begin{array}{c}0.7343^{* * *} \\
(4.15)\end{array}$ & $\begin{array}{c}1.3129 * * * \\
(3.56)\end{array}$ & $\begin{array}{c}2.2563 * * * \\
(4.01)\end{array}$ \\
\hline topten & $\begin{array}{c}0.0074^{* * *} \\
(5.02)\end{array}$ & $\begin{array}{c}0.0016^{* * *} \\
(4.56)\end{array}$ & $\begin{array}{c}0.0035^{* * *} \\
(5.45)\end{array}$ & $\begin{array}{c}0.0037^{* * *} \\
(5.63)\end{array}$ & $\begin{array}{c}0.0061^{* * *} \\
(6.92)\end{array}$ & $\begin{array}{c}0.0154^{* * *} \\
(5.00)\end{array}$ \\
\hline size & $\begin{array}{c}-0.3956^{* * *} \\
(-15.87)\end{array}$ & $\begin{array}{c}-0.1287^{* * *} \\
(-19.56)\end{array}$ & $\begin{array}{c}-0.1865^{* * *} \\
(-27.42)\end{array}$ & $\begin{array}{c}-0.2333^{* * *} \\
(-22.15)\end{array}$ & $\begin{array}{c}-0.3148^{* * *} \\
(-20.56)\end{array}$ & $\begin{array}{c}-0.4887^{* * * *} \\
(-12.66)\end{array}$ \\
\hline age & $\begin{array}{c}-0.0090 * \\
(-2.10)\end{array}$ & $\begin{array}{c}-0.0046^{* * *} \\
(-5.54)\end{array}$ & $\begin{array}{c}-0.0082 * * * \\
(-4.29)\end{array}$ & $\begin{array}{c}-0.0088^{* * * *} \\
(-5.01)\end{array}$ & $\begin{array}{c}-0.0322 * * * \\
(-4.31)\end{array}$ & $\begin{array}{c}-0.0198^{* * * *} \\
(-3.29)\end{array}$ \\
\hline stateown & $\begin{array}{c}-0.3076^{* * *} \\
(-6.74)\end{array}$ & $\begin{array}{c}-0.0960 * * * \\
(-5.23)\end{array}$ & $\begin{array}{c}-0.1669 * * * \\
(-8.90)\end{array}$ & $\begin{array}{c}-0.2133^{* * *} \\
(-9.14)\end{array}$ & $\begin{array}{c}-0.3445^{* * *} \\
(-9.16)\end{array}$ & $\begin{array}{c}-0.6713^{* * * *} \\
(-6.42)\end{array}$ \\
\hline cons & $\begin{array}{c}12.7793^{* * * *} \\
(22.38)\end{array}$ & $\begin{array}{c}4.2187^{* * *} \\
(11.96)\end{array}$ & $\begin{array}{c}5.9826^{* * *} \\
(34.87)\end{array}$ & $\begin{array}{c}9.6473^{* * * *} \\
(23.56)\end{array}$ & $\begin{array}{l}8.9502^{* * *} \\
(22.14)\end{array}$ & $\begin{array}{c}13.8047^{* * *} \\
(28.54)\end{array}$ \\
\hline Industry & \multicolumn{6}{|c|}{ Control } \\
\hline $\mathrm{N}$ & 5764 & 5764 & 5764 & 5764 & 5764 & 5764 \\
\hline $\mathrm{R}^{2}$ & 0.3112 & 0.0983 & 0.1537 & 0.2353 & 0.2378 & 0.2897 \\
\hline
\end{tabular}

$*, * *$, and ${ }^{* * *}$ are the respectively significant levels at $10 \%, 5 \%$ and $1 \% ; \mathrm{t}$ statistics in parentheses.

\subsubsection{Test of Environmental, Social and Governance Information Disclosure and Firm Value}

A regression test was conducted to verify hypothesis $\mathrm{H} 2$ and Model (3) after dividing social responsibility information disclosure into three dimensions: environment, society, and governance. The results are shown in Table 4.

The regression results showed that, when the influence of information disclosure in environment (E_dis), society (S_dis), and governance (G_dis) on firm value was investigated simultaneously, only the regression coefficient of social information disclosure (S_dis) was positive and shows an overall upward trend with the increase of the quantile, while the significance level also increases. This indicated that, the more information about society disclosed by enterprises, the more conducive it is to the growth of firm value. This result is the same as that of Qiu (2016) [32] and Brogi (2019) [34], which assumes that $\mathrm{H} 2 \mathrm{~b}$ is supported by empirical evidence. 
Table 4. Regression results of ESG and firm value.

\begin{tabular}{|c|c|c|c|c|c|c|}
\hline \multirow{2}{*}{ Variables } & \multirow{2}{*}{ OLS } & \multicolumn{5}{|c|}{ Quantile Levels } \\
\hline & & 10th & 30th & 50th & 70th & 90th \\
\hline E_dis & $\begin{array}{c}-0.0039 \\
(-1.25)\end{array}$ & $\begin{array}{c}0.0043 * * \\
(2.72)\end{array}$ & $\begin{array}{c}0.0022 \\
(2.00)\end{array}$ & $\begin{array}{c}0.0010 \\
(0.58)\end{array}$ & $\begin{array}{c}-0.0005 \\
(-0.17)\end{array}$ & $\begin{array}{c}-0.0041 \\
(-0.95)\end{array}$ \\
\hline S_dis & $\begin{array}{c}0.0058 \text { * } \\
(2.45)\end{array}$ & $\begin{array}{c}0.0024 \\
(2.1)\end{array}$ & $\begin{array}{c}0.0044^{* * *} \\
(4.52)\end{array}$ & $\begin{array}{c}0.0064^{* * *} \\
(5.99)\end{array}$ & $\begin{array}{c}0.0071^{* * *} \\
(6.10)\end{array}$ & $\begin{array}{c}0.0080^{* *} \\
(2.60)\end{array}$ \\
\hline G_dis & $\begin{array}{c}-0.0154^{* * *} \\
(-3.73)\end{array}$ & $\begin{array}{c}-0.0044 * \\
(-2.17)\end{array}$ & $\begin{array}{c}-0.0061 * * \\
(-2.98)\end{array}$ & $\begin{array}{c}-0.0044^{* *} \\
(-2.84)\end{array}$ & $\begin{array}{c}-0.0030 * \\
(-2.21)\end{array}$ & $\begin{array}{c}-0.0076 \\
(-1.58)\end{array}$ \\
\hline roe & $\begin{array}{c}-1.3290 * * \\
(-2.71)\end{array}$ & $\begin{array}{c}-0.3094^{* *} \\
(-2.93)\end{array}$ & $\begin{array}{c}-0.5839 * * \\
(-2.60)\end{array}$ & $\begin{array}{c}-1.1870 * * * \\
(-4.36)\end{array}$ & $\begin{array}{c}-1.5083^{* * *} \\
(-9.001)\end{array}$ & $\begin{array}{c}-1.7729 * * * * \\
(-3.89)\end{array}$ \\
\hline $\operatorname{lr}$ & $\begin{array}{c}0.0517^{*} \\
(2.14)\end{array}$ & $\begin{array}{l}0.0112 \\
(1.45)\end{array}$ & $\begin{array}{c}0.0225 \\
(1.26)\end{array}$ & $\begin{array}{c}0.0856^{* *} \\
(2.93)\end{array}$ & $\begin{array}{c}0.1153^{* * *} \\
(6.02)\end{array}$ & $\begin{array}{c}0.3786^{* *} \\
(3.170)\end{array}$ \\
\hline lev & $\begin{array}{c}-0.7024 \text { * } \\
(-2.24)\end{array}$ & $\begin{array}{c}-0.0909 \\
(0.46)\end{array}$ & $\begin{array}{c}-0.2117^{* *} \\
(-2.83)\end{array}$ & $\begin{array}{c}-0.3013 \text { * } \\
(-2.42)\end{array}$ & $\begin{array}{c}-0.7513^{* * *} \\
(-5.15)\end{array}$ & $\begin{array}{c}-1.6249^{* * *} \\
(-6.52)\end{array}$ \\
\hline flow & $\begin{array}{c}1.5368^{* * *} \\
(5.263)\end{array}$ & $\begin{array}{c}0.5092^{* * *} \\
(4.52)\end{array}$ & $\begin{array}{c}0.6038^{* * *} \\
(5.59)\end{array}$ & $\begin{array}{c}0.9054^{* * *} \\
(5.10)\end{array}$ & $\begin{array}{c}1.5412^{* * *} \\
(3.71)\end{array}$ & $\begin{array}{c}2.7231^{* * *} \\
(5.34)\end{array}$ \\
\hline topten & $\begin{array}{c}0.0087^{* * * *} \\
(6.03)\end{array}$ & $\begin{array}{c}0.0018^{* *} \\
(2.78)\end{array}$ & $\begin{array}{c}0.0026^{* * *} \\
(5.81)\end{array}$ & $\begin{array}{c}0.0033^{* * *} \\
(6.09)\end{array}$ & $\begin{array}{c}0.0047^{* * *} \\
(7.12)\end{array}$ & $\begin{array}{c}0.0353^{* * *} \\
(7.74)\end{array}$ \\
\hline size & $\begin{array}{c}-0.3911^{* * *} \\
(-14.57)\end{array}$ & $\begin{array}{c}-0.1390 * * * \\
(-13.72)\end{array}$ & $\begin{array}{c}-0.1943^{* * *} \\
(-19.54)\end{array}$ & $\begin{array}{c}-0.2594^{* * *} \\
(-27.62)\end{array}$ & $\begin{array}{c}-0.3078 * * * \\
(-20.03)\end{array}$ & $\begin{array}{c}-0.3910^{* * * *} \\
(-17.48)\end{array}$ \\
\hline age & $\begin{array}{c}-0.0055 \\
(-1.62)\end{array}$ & $\begin{array}{c}-0.0057^{* * *} \\
(-4.36)\end{array}$ & $\begin{array}{c}-0.0054^{* * *} \\
(-3.96)\end{array}$ & $\begin{array}{c}-0.0037^{* * *} \\
(-4.43)\end{array}$ & $\begin{array}{c}-0.0145^{* * *} \\
(-3.83)\end{array}$ & $\begin{array}{c}-0.0111^{* * * *} \\
(-3.52)\end{array}$ \\
\hline stateown & $\begin{array}{c}-0.2573^{* * *} \\
(-5.99)\end{array}$ & $\begin{array}{c}-0.1266^{* * *} \\
(-7.63)\end{array}$ & $\begin{array}{c}-0.1325^{* * *} \\
(-9.81)\end{array}$ & $\begin{array}{c}-0.2016^{* * *} \\
(-8.00)\end{array}$ & $\begin{array}{c}-0.3115^{* * *} \\
(-10.10)\end{array}$ & $\begin{array}{c}-0.6327^{* * *} \\
(-6.37)\end{array}$ \\
\hline cons & $\begin{array}{c}11.454^{* * * *} \\
(22.81)\end{array}$ & $\begin{array}{c}5.1436^{* * *} \\
(21.05)\end{array}$ & $\begin{array}{c}6.5492 * * * \\
(22.87)\end{array}$ & $\begin{array}{c}7.0158^{* * * *} \\
(36.85)\end{array}$ & $\begin{array}{c}9.3473^{* * * *} \\
(29.73)\end{array}$ & $\begin{array}{c}14.9989^{* * *} \\
(20.78)\end{array}$ \\
\hline Industry & & & & & & \\
\hline $\mathrm{N}$ & 5764 & 5764 & 5764 & 5764 & 5764 & 5764 \\
\hline $\mathrm{R}^{2}$ & 0.274 & 0.1116 & 0.1536 & 0.2141 & 0.2303 & 0.3751 \\
\hline
\end{tabular}

The regression coefficient of environmental information disclosure (E_dis) was not significant, except the 10th quantile was positively significant at the level of $5 \%$, and the research hypothesis $\mathrm{H} 2 \mathrm{a}$ was verified. A possible reason for this is that low-value enterprises are more willing to win the trust of investors by disclosing more information, so they choose to disclose environmental information. Meanwhile, the cost of high-value enterprises disclosing environmental information is higher than that of disclosing information regarding other dimensions [33]; thus, the information of other dimensions partially replaces the impact effect of environmental information on firm value.

The regression coefficient of governance information disclosure (G_dis) was negative on a whole and tended to rise with an increase in the quantile coefficient, which indicated that governance information disclosure had a negative impact on firm value; that is, the more enterprises disclose governance information, the less conducive it is to firm value growth, assuming that $\mathrm{H} 3 \mathrm{c}$ is not supported by the empirical test. The reason for this result may be that the high transparency of information disclosure in corporate governance may not reflect the quality of its information. If the information itself is not well explained, it may even lead to misunderstanding among investors, which is even worse for the improvement of firm value.

\subsubsection{Test of The Interactive Impact of Green Innovation and ESG Information Disclosure on} Firm Value

To verify the interactive effect of green innovation and social responsibility information disclosure (after the division) on firm value, Model (4) was empirically tested. In this study, the intersection of environmental information disclosure, social information disclosure, and governance information 
disclosure in green innovation and social responsibility was added, and the quantile was expressed with GI $\times$ E_dis, GI × S_dis, and GI × G_dis.

As can be seen from Table 5, the regression coefficient of green innovation and environmental information disclosure (GI $\times$ E_dis) was, in general, zero and failed to pass the significance test. This shows that green innovation and environmental information disclosure have no significant interactive impact on firm value. The OLS regression also supported this result, assuming that H3a failed to pass the test.

Table 5. Regression results of ESG and green innovation on enterprise value.

\begin{tabular}{|c|c|c|c|c|c|c|}
\hline \multirow{2}{*}{ Variables } & \multirow{2}{*}{ OLS } & \multicolumn{5}{|c|}{ Quantile Levels } \\
\hline & & 10th & 30th & 50th & 70th & 90th \\
\hline GI & $\begin{array}{c}0.0014^{* * *} \\
(3.46)\end{array}$ & $\begin{array}{c}0.0016^{* * *} \\
(4.80)\end{array}$ & $\begin{array}{c}0.0019 * * * \\
(6.04)\end{array}$ & $\begin{array}{c}0.0017^{* * *} \\
(4.15)\end{array}$ & $\begin{array}{c}0.0017^{* *} \\
(2.93)\end{array}$ & $\begin{array}{c}0.0007 \\
(1.22)\end{array}$ \\
\hline E_dis & $\begin{array}{l}-0.0044 \\
(-1.30)\end{array}$ & $\begin{array}{c}0.0030^{*} \\
(2.15)\end{array}$ & $\begin{array}{r}0.0027 \\
(1.70)\end{array}$ & $\begin{array}{c}0.0013 \\
(0.98)\end{array}$ & $\begin{array}{c}-0.0004 \\
(-0.10)\end{array}$ & $\begin{array}{l}-0.0015 \\
(-0.21)\end{array}$ \\
\hline S_dis & $\begin{array}{c}0.0052 * \\
(2.33)\end{array}$ & $\begin{array}{c}0.0028 \text { * } \\
(2.45)\end{array}$ & $\begin{array}{c}0.0054^{* * *} \\
(4.56)\end{array}$ & $\begin{array}{c}0.0082^{* * *} \\
(5.43)\end{array}$ & $\begin{array}{c}0.0088^{* * *} \\
(5.07)\end{array}$ & $\begin{array}{c}0.0076 \text { * } \\
(2.43)\end{array}$ \\
\hline G_dis & $\begin{array}{c}-0.0158^{* * *} \\
(-3.77)\end{array}$ & $\begin{array}{c}-0.0027^{* *} \\
(-3.08)\end{array}$ & $\begin{array}{c}-0.0049^{* * *} \\
(-3.96)\end{array}$ & $\begin{array}{c}-0.0040^{* *} \\
(-2.56)\end{array}$ & $\begin{array}{c}-0.0024 * \\
(-2.10)\end{array}$ & $\begin{array}{l}-0.0078 \\
(-1.30)\end{array}$ \\
\hline $\mathrm{GI} \times$ E_dis & $\begin{array}{c}0.0000 \\
(1.00)\end{array}$ & $\begin{array}{c}0.0000 \\
(0.31)\end{array}$ & $\begin{array}{c}0.0000 \\
(0.45)\end{array}$ & $\begin{array}{c}0.0000 \\
(0.05)\end{array}$ & $\begin{array}{c}-0.0000 \\
(-0.62)\end{array}$ & $\begin{array}{l}-0.0002 \\
(-1.50)\end{array}$ \\
\hline GI $\times$ S_dis & $\begin{array}{c}-0.0001 * * \\
(-4.58)\end{array}$ & $\begin{array}{c}-0.0001^{* * *} \\
(-3.65)\end{array}$ & $\begin{array}{c}-0.0001^{* * *} \\
(-3.74)\end{array}$ & $\begin{array}{c}-0.0001 * \\
(-2.30)\end{array}$ & $\begin{array}{c}-0.0001 * \\
(-2.15)\end{array}$ & $\begin{array}{l}-0.0000 \\
(-0.60)\end{array}$ \\
\hline GI $\times$ G_dis & $\begin{array}{c}0.0003 \text { * } \\
(2.45)\end{array}$ & $\begin{array}{c}0.0000 \\
(0.79)\end{array}$ & $\begin{array}{c}0.0001 \text { * } \\
(2.14)\end{array}$ & $\begin{array}{c}0.0001 \text { * } \\
(2.30)\end{array}$ & $\begin{array}{c}0.0002 * \\
(2.45)\end{array}$ & $\begin{array}{c}0.0003 \text { * } \\
(2.58)\end{array}$ \\
\hline roe & $\begin{array}{c}-1.0352 * * \\
(-2.73)\end{array}$ & $\begin{array}{c}-0.2847 \text { * } \\
(-2.44)\end{array}$ & $\begin{array}{c}-0.6342 * \\
(-2.44)\end{array}$ & $\begin{array}{c}-1.537^{* * *} \\
(-4.80)\end{array}$ & $\begin{array}{c}-1.5628^{* * *} \\
(-5.39)\end{array}$ & $\begin{array}{c}-1.7685 * * \\
(-3.00)\end{array}$ \\
\hline $\operatorname{lr}$ & $\begin{array}{c}0.0352 * \\
(2.24)\end{array}$ & $\begin{array}{c}0.0124 \\
(1.20)\end{array}$ & $\begin{array}{c}0.0198 \\
(0.90)\end{array}$ & $\begin{array}{c}0.0771 * * * \\
(3.92)\end{array}$ & $\begin{array}{c}0.1185^{* * *} \\
(4.80)\end{array}$ & $\begin{array}{c}0.2176^{* * * *} \\
(3.69)\end{array}$ \\
\hline lev & $\begin{array}{c}-0.6511^{* *} \\
(-2.87)\end{array}$ & $\begin{array}{c}0.0633 \\
(1.02)\end{array}$ & $\begin{array}{c}-0.1876^{* * *} \\
(-3.59)\end{array}$ & $\begin{array}{c}-0.2662 * * * \\
(-3.73)\end{array}$ & $\begin{array}{c}-0.5257^{* * * *} \\
(-4.01)\end{array}$ & $\begin{array}{c}-1.4338^{* * *} \\
(-4.22)\end{array}$ \\
\hline flow & $\begin{array}{c}1.6583^{* * *} \\
(4.53)\end{array}$ & $\begin{array}{c}0.4387^{* * *} \\
(4.85)\end{array}$ & $\begin{array}{c}0.6354^{* * *} \\
(6.43)\end{array}$ & $\begin{array}{c}0.8346^{* * *} \\
(4.00)\end{array}$ & $\begin{array}{c}1.3165^{* * *} \\
(4.73)\end{array}$ & $\begin{array}{c}2.4529 * * * \\
(4.76)\end{array}$ \\
\hline topten & $\begin{array}{c}0.0075^{* * *} \\
(4.76)\end{array}$ & $\begin{array}{c}0.0016^{* * *} \\
(4.32)\end{array}$ & $\begin{array}{c}0.0029^{* * *} \\
(4.59)\end{array}$ & $\begin{array}{c}0.0043^{* * *} \\
(4.34)\end{array}$ & $\begin{array}{c}0.0063^{* * *} \\
(4.53)\end{array}$ & $\begin{array}{c}0.0142^{* * *} \\
(8.01)\end{array}$ \\
\hline size & $\begin{array}{c}-0.4067^{* * *} \\
(-15.95)\end{array}$ & $\begin{array}{c}-0.1588^{* * *} \\
(-17.74)\end{array}$ & $\begin{array}{c}-0.1967^{* * * *} \\
(-21.98)\end{array}$ & $\begin{array}{c}-0.2742^{* * *} \\
(-26.09)\end{array}$ & $\begin{array}{c}-0.3441^{* * *} \\
(-19.70)\end{array}$ & $\begin{array}{c}-0.4783^{* * *} \\
(-10.57)\end{array}$ \\
\hline age & $\begin{array}{c}-0.0067 \\
(-1.63)\end{array}$ & $\begin{array}{c}-0.0059 * * * \\
(-5.05)\end{array}$ & $\begin{array}{c}-0.0073^{* * *} \\
(-4.52)\end{array}$ & $\begin{array}{c}-0.0089 * * * \\
(-5.53)\end{array}$ & $\begin{array}{c}-0.0160 * * * \\
(-3.70)\end{array}$ & $\begin{array}{c}-0.0222 * * * \\
(-3.37)\end{array}$ \\
\hline stateown & $\begin{array}{c}-0.2869^{* * *} \\
(-6.34)\end{array}$ & $\begin{array}{c}-0.1235^{* * *} \\
(-8.10)\end{array}$ & $\begin{array}{c}-0.1635^{* * *} \\
(-6.96)\end{array}$ & $\begin{array}{c}-0.2230^{* * *} \\
(-8.77)\end{array}$ & $\begin{array}{c}-0.3487 * * * \\
(-9.93)\end{array}$ & $\begin{array}{c}-0.6355^{* * *} \\
(-5.71)\end{array}$ \\
\hline cons & $\begin{array}{c}12.674^{* * *} \\
(21.68)\end{array}$ & $\begin{array}{c}3.8437 * * * \\
(18.55)\end{array}$ & $\begin{array}{c}5.5877^{* * *} \\
(26.32)\end{array}$ & $\begin{array}{c}7.0865^{* * *} \\
(27.67)\end{array}$ & $\begin{array}{c}9.5478 * * * \\
(22.48)\end{array}$ & $\begin{array}{c}12.763 \text { *** } \\
(10.67)\end{array}$ \\
\hline Industry & & & & & & \\
\hline $\mathrm{N}$ & 5764 & 5764 & 5764 & 5764 & 5764 & 5764 \\
\hline $\mathrm{R}^{2}$ & 0.3004 & 0.1087 & 0.1523 & 0.1967 & 0.2253 & 0.2890 \\
\hline
\end{tabular}

$*^{* *}$, and ${ }^{* * *}$ are the respectively significant levels at $10 \%, 5 \%$ and $1 \%$; t statistics in parentheses.

The regression coefficient of each quantile for green innovation and social information disclosure $(\mathrm{GI} \times \mathrm{S}$ _dis) was negative, and the significance level decreased with the increase of the quantile, which indicates that the overall interaction effect of green innovation and social information disclosure (GI $\times$ S_dis) on firm value is substitution, but the substitution effect of the two was weakened after the 50th quantile, with the significance level decreasing. This was different from the results obtained by the OLS regression. Examining the OLS regression results, they show that the impact of green innovation and social information disclosure on firm value takes on a substitution effect, assuming that $\mathrm{H} 3 \mathrm{~b}$ is verified. 
However, quantile regression shows that both factors take on a substitution effect at the beginning, but with the increase of firm value, this effect decreases, assuming that $\mathrm{H} 3 \mathrm{~b}$ is verified. This is also different from the conclusions of existing research. Previous studies on innovation and social responsibility have only concluded that these two factors have a substitution effect on each other [6,7]. However, this study found that green innovation only has a substitution effect on social information disclosure, and this effect gradually decreases with the increase of firm value.

Finally, the regression coefficient of green innovation and governance information disclosure (GI $\times$ G_dis) was positive and significant in the middle and high quantiles, but there was no substitution effect between them, assuming that $\mathrm{H} 3 \mathrm{c}$ was not verified. This shows that, for medium- and high-level firm value, with the increase of green innovation level, the negative impact of governance information disclosure on firm value can be significantly inhibited.

\section{Robustness Tests}

This paper takes the following approaches to testing to ensure robust results.

First, considering the mutual causality between social responsibility information disclosure and firm value, this paper uses Jayaraman and Milbourn's [46] method for reference, selecting the one-period lag ESG information disclosure as a tool variable and using the 2-stage least square method (2sls) to control for endogeneity in the regression test. As shown in Table A2, the results were basically consistent with the above after controlling for endogeneity.

Second, considering the lag effect of green innovation's impact on firm value, this paper regressed green innovation after a one-period lag to maintain the stability of the results. The results show that it is basically consistent with the above results and still supports hypothesis H1. See Table A3 for the specific results.

\section{Conclusions and Policy Recommendations}

\subsection{Conclusions}

Based on the micro data on China's enterprises, in combination with the comparison of the methods of OLS and quantile and using theoretical analysis and empirical testing, this paper draws relevant conclusions. Since the quantile method is able to test the influence of green innovation and social responsibility on firm value at different levels, this study was able to draw the following conclusions: (1) Green innovation plays a stronger role in promoting medium- and high-level firm value. (2) In terms of environment, information disclosure can only significantly promote low-level firm value. The positive impact of social information disclosure on firm value is stronger with the increase of firm value level, and the negative impact of governance information disclosure on firm value is stronger with the increase of firm value level. (3) Different from conclusions scholars previously have drawn, the relationship between innovation and social responsibility is always substitutive [6,7]. Social information disclosure and green innovation only have a substitution effect on low-level firm value, and the substitution effect will gradually weaken as the firm value increases. Finally, the paper found that, with the increase of firm value, green innovation can inhibit the adverse effect of governance information disclosure on firm value.

\subsection{Policy Recommendations}

The findings of this study can be divided into several aspects, as follows.

For enterprises, green innovation can not only promote green production, accelerating their own green transformation, but also give rise to economic benefits. Enterprise managers should consider the positive impact of green innovation on their enterprises, increase investments in the research and development of cleaner production technologies, and promote the coordination between micro enterprises and macro policies. Secondly, at present, the overall level of ESG disclosure of the enterprises of the countries whose main economic support is industrial development is not high, 
and problems in environmental information disclosure are particularly prominent. In addition to the mandatory disclosure of specific enterprises, enterprises mostly disclose information voluntarily, which leads to the majority of high-value enterprises choosing social information disclosure, which costs less, and reducing environmental information disclosure, thus replacing the impact of environmental information disclosure on the value of high-level enterprises. The same is true for governance: the excessive pursuit of information disclosure is not conducive to the improvement of the business performance of Chinese enterprises. Only social information disclosure can promote overall firm value. In view of the above situation, when disclosing a social responsibility report, enterprises should adjust the content of the report accordingly. First, enterprises should improve the transparency of environmental information, increase the amount of environmental information disclosed, and improve the level of this disclosure. Besides, they should also improve the transparency of social information, which can significantly improve their future valuation on the whole. Finally, the disclosure of governance information is detrimental to the improvement of firm value, and it requires enterprises to reduce the amount disclosed, improve the quality, enhance the interpretation, screen out important information, and disclose valuable information.

For the government and regulatory authorities, sustainable development is always the primary issue related to the future development of the countries dominated by industrial economy. As a tangible hand, the government should adjust the relationship between ecology and society. First of all, it should give financial incentives to enterprises that take the initiative to assume social responsibility and the timely disclosure of information, increase their financial allocation, and stipulate the use of green special funds, so as to alleviate the contradiction between green innovation and social responsibility caused by the shortage of funds of low-firm value companies. Secondly, the regulatory agencies concerned should improve the construction of their ESG information disclosure system and promote the improvement of ESG system standards. In the future, the exchanges of various countries will gradually establish a mandatory ESG information disclosure system, improve the intensity of social responsibility information disclosure in all dimensions, enable enterprises to disclose more environmental information, improve the quality of governance information disclosure, and enhance the strength of the influence of policy on social information disclosure, all so that investors can receive the social responsibility information of different dimensions to judge the value of their corporate investments. Finally, there should be certain incentives for enterprises to disclose information in a standardized manner, and imposing penalties, such as fines, warnings, or delisting, on enterprises that do not timely disclose ESG information or falsify information is recommended.

For investors, socially responsible investing is a trend guiding future economic development of all countries in the world. In order to comply with this trend, financial institutions, such as banks, securities, and insurance, should support the complete disclosure of ESG information as well as the outstanding performance or the financing of green projects, solve the issue of insufficient funds, and resolve the consequent contradiction between social responsibility and green innovation. Moreover, they should give full play to the leading advantages of large institutional investors, keep long-term funds in "green" enterprises, realize a virtuous circle of funds, and promote the future development of green economy. Additionally, investors should consider the role of non-financial information, examine the impact of the different dimensions of social responsibility information on firm value, and judge the investment value of enterprises from different perspectives.

Author Contributions: Conceptualization, F.Z. and L.L.; methodology, F.Z. and X.Q.; formal analysis, F.Z. and L.L.; investigation, X.Q. and L.L.; resources, F.Z.; writing—original draft preparation, F.Z. and L.L.; writing-review and editing, X.Q. and L.L. All authors have read and agreed to the published version of the manuscript.

Funding: This paper is financially supported by the National Natural Science Foundation of China (Grant number 71704098, 71874102), Natural Science Foundation of Shandong Province (Grant number ZR2019QG009).

Acknowledgments: We are grateful to all the funding agencies, the editors and the anonymous reviewers for valuable comments and suggestions.

Conflicts of Interest: The authors declare no conflict of interest. 


\section{Appendix A}

Table A1. Variables of correlation coefficient.

\begin{tabular}{|c|c|c|c|c|c|c|c|c|c|c|c|c|c|}
\hline Variables & (1) & (2) & (3) & (4) & (5) & (6) & (7) & (8) & (9) & (10) & (11) & (12) & (13) \\
\hline TobinQ & 1.000 & & & & & & & & & & & & \\
\hline GI & -0.048 & 1.000 & & & & & & & & & & & \\
\hline E_dis & -0.149 & 0.138 & 1.000 & & & & & & & & & & \\
\hline S_dis & -0.101 & 0.131 & 0.522 & 1.000 & & & & & & & & & \\
\hline G_dis & -0.213 & 0.101 & 0.337 & 0.350 & 1.000 & & & & & & & & \\
\hline roe & 0.327 & 0.022 & -0.017 & 0.027 & -0.065 & 1.000 & & & & & & & \\
\hline $\operatorname{lr}$ & 0.264 & -0.030 & -0.084 & -0.046 & -0.119 & 0.150 & 1.000 & & & & & & \\
\hline lev & -0.404 & 0.037 & 0.117 & 0.097 & 0.195 & -0.411 & -0.437 & 1.000 & & & & & \\
\hline flow & 0.272 & -0.024 & -0.075 & -0.049 & -0.074 & 0.293 & 0.312 & -0.354 & 1.000 & & & & \\
\hline topten & 0.003 & 0.064 & 0.199 & 0.129 & 0.121 & 0.144 & -0.013 & 0.033 & 0.043 & 1.000 & & & \\
\hline size & -0.405 & 0.229 & 0.378 & 0.314 & 0.387 & -0.059 & -0.239 & 0.522 & -0.191 & 0.310 & 1.000 & & \\
\hline age & -0.114 & -0.007 & 0.038 & 0.053 & 0.176 & -0.065 & -0.047 & 0.133 & -0.079 & -0.194 & 0.101 & 1.000 & \\
\hline stateown & -0.228 & 0.041 & 0.123 & 0.095 & 0.202 & -0.157 & -0.113 & 0.215 & -0.038 & 0.116 & 0.299 & 0.107 & 1.000 \\
\hline
\end{tabular}

Table A2. 2sls regression results.

\begin{tabular}{cc}
\hline Variables & 2sls \\
\hline E_dis & -0.0018 \\
& $(-0.56)$ \\
S_dis & $0.0043^{*}$ \\
& $(2.20)$ \\
G_dis & $-0.0195^{* * *}$ \\
controls & $(-3.97)$ \\
cons & YES \\
Industry & Control \\
N & 4697 \\
R2 & 0.3022
\end{tabular}

$*, * *$, and ${ }^{* * *}$ are the respectively significant levels at $10 \%, 5 \%$ and $1 \%$; t statistics in parentheses.

Table A3. Regression results of green innovation lag one period.

\begin{tabular}{|c|c|c|c|c|c|c|}
\hline \multirow{2}{*}{ Variables } & \multirow{2}{*}{ OLS } & \multicolumn{5}{|c|}{ Quantile Levels } \\
\hline & & 10th & 30th & 50th & 70th & 90th \\
\hline$G I_{t-1}$ & $\begin{array}{c}0.0016^{* * *} \\
(5.23)\end{array}$ & $\begin{array}{c}0.0005 \text { * } \\
(2.14)\end{array}$ & $\begin{array}{c}0.0006 \text { * } \\
(2.00)\end{array}$ & $\begin{array}{c}0.0010 \text { * } \\
(2.35)\end{array}$ & $\begin{array}{c}0.0010 \text { ** } \\
(2.58)\end{array}$ & $\begin{array}{c}0.0009 \\
(1.09)\end{array}$ \\
\hline roe & $\begin{array}{c}-0.6934^{* *} \\
(-2.53)\end{array}$ & $\begin{array}{c}-0.2846^{* *} \\
(-2.95)\end{array}$ & $\begin{array}{c}-0.5289 * * * \\
(-4.58)\end{array}$ & $\begin{array}{c}-1.1657^{* * *} \\
(-4.79)\end{array}$ & $\begin{array}{c}-1.6693^{* * *} \\
(-6.45)\end{array}$ & $\begin{array}{c}-1.3072^{* * *} \\
(-3.62)\end{array}$ \\
\hline $\operatorname{lr}$ & $\begin{array}{c}0.0541 \text { * } \\
(2.24)\end{array}$ & $\begin{array}{c}0.0184 \\
(1.66)\end{array}$ & $\begin{array}{c}0.0312 \\
(1.21)\end{array}$ & $\begin{array}{c}0.1095^{* * *} \\
(4.23)\end{array}$ & $\begin{array}{c}0.1269 * * * \\
(5.66)\end{array}$ & $\begin{array}{c}0.1891 \text { ** } \\
(3.10)\end{array}$ \\
\hline lev & $\begin{array}{c}-0.7012 \text { ** } \\
(-2.64)\end{array}$ & $\begin{array}{c}0.0755 \text { * } \\
(2.30)\end{array}$ & $\begin{array}{c}-0.1654 \\
(-1.89)\end{array}$ & $\begin{array}{c}-0.2452 \text { ** } \\
(-2.65)\end{array}$ & $\begin{array}{c}-0.5473^{* * *} \\
(-3.45)\end{array}$ & $\begin{array}{c}-1.5710^{* * *} \\
(-4.21)\end{array}$ \\
\hline flow & $\begin{array}{c}2.0623 * * * \\
(5.44)\end{array}$ & $\begin{array}{c}0.4511^{* * *} \\
(4.34)\end{array}$ & $\begin{array}{c}0.6584^{* * *} \\
(4.42)\end{array}$ & $\begin{array}{c}0.9531^{* * *} \\
(4.50)\end{array}$ & $\begin{array}{c}1.6315 * * * \\
(6.70)\end{array}$ & $\begin{array}{c}3.0034^{* * *} \\
(3.53)\end{array}$ \\
\hline topten & $\begin{array}{c}0.0034^{* * *} \\
(4.37)\end{array}$ & $\begin{array}{c}0.0020^{* *} \\
(2.66)\end{array}$ & $\begin{array}{c}0.0022^{* * *} \\
(3.45)\end{array}$ & $\begin{array}{c}0.0053^{* * *} \\
(5.78)\end{array}$ & $\begin{array}{c}0.0023^{* * *} \\
(3.16)\end{array}$ & $\begin{array}{c}0.0150^{* * *} \\
(7.30)\end{array}$ \\
\hline size & $\begin{array}{c}-0.3978^{* * *} \\
(-16.34)\end{array}$ & $\begin{array}{c}-0.1232^{* * *} \\
(-15.78)\end{array}$ & $\begin{array}{c}-0.2056^{* * *} \\
(-23.36)\end{array}$ & $\begin{array}{c}-0.2576^{* * *} \\
(-31.47)\end{array}$ & $\begin{array}{c}-0.3422 * * * \\
(-13.76)\end{array}$ & $\begin{array}{c}-0.5149^{* * *} \\
(-14.58)\end{array}$ \\
\hline age & $\begin{array}{c}-0.0212^{* * *} \\
(-4.32)\end{array}$ & $\begin{array}{c}-0.0092^{* * *} \\
(-4.34)\end{array}$ & $\begin{array}{c}-0.0134^{* * *} \\
(-5.83)\end{array}$ & $\begin{array}{c}-0.0152 * * * \\
(-4.72)\end{array}$ & $\begin{array}{c}-0.0211^{* * *} \\
(-4.95)\end{array}$ & $\begin{array}{c}-0.0301^{* * *} \\
(-4.04)\end{array}$ \\
\hline stateown & $\begin{array}{c}-0.2753^{* * *} \\
(-5.71)\end{array}$ & $\begin{array}{c}-0.1045^{* * *} \\
(-6.35)\end{array}$ & $\begin{array}{c}-0.1479 * * * \\
(-6.10)\end{array}$ & $\begin{array}{c}-0.2034^{* * *} \\
(-8.23)\end{array}$ & $\begin{array}{c}-0.3155^{* * *} \\
(-7.93)\end{array}$ & $\begin{array}{c}-0.5134^{* * *} \\
(-4.23)\end{array}$ \\
\hline cons & $\begin{array}{c}13.523^{* * *} \\
(24.24)\end{array}$ & $\begin{array}{c}4.8648^{* * *} \\
(18.66)\end{array}$ & $\begin{array}{c}6.8342^{* * *} \\
(31.27)\end{array}$ & $\begin{array}{c}7.8549 * * * \\
(37.90)\end{array}$ & $\begin{array}{c}9.5732 * * * \\
(22.82)\end{array}$ & $\begin{array}{c}15.947 * * \\
(20.94)\end{array}$ \\
\hline Industry & \multicolumn{6}{|c|}{ Control } \\
\hline $\mathrm{N}$ & 4697 & 4697 & 4697 & 4697 & 4697 & 4697 \\
\hline $\mathrm{R}^{2}$ & 0.3068 & 0.0953 & 0.1745 & 0.2184 & 0.2527 & 0.3089 \\
\hline
\end{tabular}

${ }^{*}{ }^{* *}$, and ${ }^{* * *}$ are the respectively significant levels at $10 \%, 5 \%$ and $1 \%$; $t$ statistics in parentheses. 


\section{References}

1. Zhang, D.; Rong, Z.; Ji, Q. Green innovation and firm performance: Evidence from listed companies in China. Resour. Conserv. Recy. 2019, 144, 48-55. [CrossRef]

2. Anser, M.; Zhang, Z.; Kanwal, L. Moderating effect of innovation on corporate social responsibility and firm performance in realm of sustainable development. Corp. Soc. Responsib. Environ. Manag. 2018, 25, 799-806. [CrossRef]

3. Martinez-Conesa, I.; Soto-Acosta, P.; Palacios-Manzano, M. Corporate social responsibility and its effect on innovation and firm performance: An empirical research in SMEs. J. Clean. Prod. 2017, 142, 2374-2383. [CrossRef]

4. Carrasco-Monteagudo, I.; Buendía-Martínez, I. Corporate social responsibility: A crossroad between changing values, innovation and internationalisation. Eur. J. Int. Manag. 2013, 7, 295-314. [CrossRef]

5. Mcwilliams, A.; Siegel, D. Corporate Social Responsibility and Financial Performance: Correlation or Misspecification? Strateg. Manag. J. 2000, 21, 603-609. [CrossRef]

6. Coluccia, D.; Dabić, M.; Del Giudice, M.; Fontana, S.; Solimene, S. R\&D Innovation Indicator and Its Effects on the Market. An Empirical Assessment from a Financial Perspective. Available online: https: //www.sciencedirect.com/science/article/pii/S0148296319302577 (accessed on 23 April 2019).

7. Luo, X.; Bhattacharya, C.B. Corporate Social Responsibility, Customer Satisfaction, and Market Value. J. Mark. 2006, 70, 1-18. [CrossRef]

8. Sun, H.; Edziah, B.K.; Sun, C.; Kporsu, A.K. Institutional quality, green innovation and energy efficiency. Energy Policy 2019, 135, 111002. [CrossRef]

9. Fang, Z.; Bai, H.; Bilan, Y. Evaluation Research of Green Innovation Efficiency in China's Heavy Polluting Industries. Sustainability 2020, 12, 146. [CrossRef]

10. Minutolo, M.; Kristjanpoller, W.; Stakeley, J. Exploring environmental, social, and governance disclosure effects on the S\&P 500 financial performance. Bus. Strateg. Environ. 2019, 28, 1083-1095.

11. Backhaus, K.B.; Stone, B.A.; Heiner, K. Exploringthe Relationship Between Corporate Social Performance and Employer Attractiveness. Bus. Soc. 2002, 41, 292-318. [CrossRef]

12. Ting, I.W.K.; Azizan, N.A.; Bhaskaran, R.K.; Sukumaran, S.K. Corporate Social Performance and Firm Performance: Comparative Study among Developed and Emerging Market Firms. Sustainability 2020, 12, 26. [CrossRef]

13. Lys, T.Z.; Naughton, J.P.; Wang, C. Signaling Through Corporate Accountability Reporting. J. Account. Econ. 2015, 60, 56-72. [CrossRef]

14. Waddock, S.A.; Graves, S.B. The corporate social performance-financial performance link. Strateg. Manag. J. 1997, 18, 303-319. [CrossRef]

15. Brammer, S.; Brooks, C.; Pavelin, S. Corporate Social Performance and Stock Returns: UK Evidence from Disaggregate Measures. Financ. Manag. 2006, 35, 97-116. [CrossRef]

16. Yang, X.; Zhang, Z.; Luo, W.; Tang, Z.; Gao, X.; Wan, Z.; Zhang, X. The Impact of Government Role on High-Quality Innovation Development in Mainland China. Sustainability 2019, 11, 5780. [CrossRef]

17. Porter, M.E.; Claas, V.D.L. Toward a New Conception of the Environment-Competitiveness Relationship. J. Econ. Perspect. 1995, 9, 97-118. [CrossRef]

18. Jiang, W.; Chai, H.; Shao, J.; Feng, T. Green entrepreneurial orientation for enhancing firm performance: A dynamic capability perspective. J. Clean. Prod. 2018, 198, 1311-1323. [CrossRef]

19. Rezende, L.D.A.; Bansi, A.C.; Alves, M.F.R.; Galina, S.V.R. Take your time: Examining when green innovation affects financial performance in multinationals. J. Clean. Prod. 2019, 233, 993-1003. [CrossRef]

20. Wang, Q.; Qu, J.; Wang, B.; Wang, P.; Yang, T. Green technology innovation development in China in 1990-2015. Sci. Total. Environ. 2019, 696, 134008. [CrossRef]

21. Stucki, T. Which firms benefit from investments in green energy technologies?-The effect of energy costs. Res. Policy 2019, 48, 546-555. [CrossRef]

22. Michelson, G.; Wailes, N.; Laan, S.V.D.; Frost, G. Ethical Investment Processes and Outcomes. J. Bus. Ethics. 2004, 52, 1-10. [CrossRef]

23. He, L.; Zhang, L.; Zhong, Z.; Wang, D.; Wang, F. Green credit, renewable energy investment and green economy development: Empirical analysis based on 150 listed companies of China. J. Clean. Prod. 2019, 208, 363-372. [CrossRef] 
24. Spence, A.M. Market Signaling: Informational Transfer in Hiring and Related Screening Processes; Harvard University Press: Cambridge, MA, USA, 1974; Volume 143.

25. Cheng, B.; Ioannou, I.; Serafeim, G. Corporate Social Responsibility and Access to Finance. Strateg. Manag. J. 2014, 35, 1-23. [CrossRef]

26. Kim, J.; Cho, K.; Park, C.K. Does CSR Assurance Affect the Relationship between CSR Performance and Financial Performance? Sustainability 2019, 11, 5682. [CrossRef]

27. Yu, P.Y.; Guo, C.Q.; Luu, B.V. Environmental, social and governance transparency and firm value. Bus. Strateg. Environ. 2018, 27, 987-1004. [CrossRef]

28. Friedman, M. The Social Responsibility of Business is to Increase its Profits. N. Y. Times Mag. 1970, 13, 173-178.

29. Duque-Grisales, E.; Aguilera-Caracuel, J. Environmental, Social and Governance (ESG) Scores and Financial Performance of Multilatinas: Moderating Effects of Geographic International Diversification and Financial Slack. Available online: https://link.springer.com/article/10.1007\%2Fs10551-019-04177-w (accessed on 16 May 2019).

30. Aouadi, A.; Marsat, S. Do ESG Controversies Matter for Firm Value? Evidence from International Data. J. Bus. Ethics. 2018, 151, 1027-1047. [CrossRef]

31. Orens, R.; Aerts, W.; Cormier, D. Web-based non-financial disclosure and cost of finance. J. Bus. Financ. Account. 2010, 37, 1057-1093. [CrossRef]

32. Qiu, Y.; Shaukat, A.; Tharyan, R. Environmental and social disclosures: Link with corporate financial performance. Brit. Account. Rev. 2016, 48, 102-116. [CrossRef]

33. Qiu, M.; Yin, H. An analysis of enterprises' financing cost with ESG Performance under the background of ecological civilization construction. J. Quant. Technol. Econ. 2019, 36, 108-123.

34. Sen, S.; Bhattacharya, C.B. Does Doing Good Always Lead to Doing Better? Consumer Reactions to Corporate Social Responsibility. J. Mark. Res. 2001, 38, 225-243. [CrossRef]

35. Brogi, M.; Lagasio, V. Environmental, social, and governance and company profitability: Are financial intermediaries different? Corp. Soc. Responsib. Environ. Manag. 2019, 26, 576-587. [CrossRef]

36. Zyglidopoulos, S.C.; Georgiadis, A.P.; Carroll, C.E.; Siegel, D.S. Does media attention drive corporate social responsibility? J. Bus. Res. 2012, 65, 1622-1627. [CrossRef]

37. Brainard, W.C.; Tobin, J. Pitfalls in Financial Model Building. Am. Econ. Rev. 1968, 58, 99-122.

38. Tobin, J. A General Equilibrium Approach to Monetary Theory. J. Money Credit Bank. 1969, 1, 15-29. [CrossRef]

39. Miroshnychenko, I.; Barontini, R.; Testa, F. Green practices and financial performance: A global outlook. J. Clean. Prod. 2017, 147, 340-351. [CrossRef]

40. Rennings, K. Redefining innovation-Eco-innovation research and the contribution from ecological economics. Ecol. Econ. 2000, 32, 319-332. [CrossRef]

41. Oltra, V.; Jean, M.S. Sectoral systems of environmental innovation: An application to the French automotive industry. Technol. Forecast. Soc. 2009, 76, 567-583. [CrossRef]

42. Koenker, R.; Bassett, G. Regression Quantiles. Econometrica 1978, 46, 33-50. [CrossRef]

43. De Silva, P.N.K.; Simons, S.J.R.; Stevens, P. Economic impact analysis of natural gas development and the policy implications. Energy Policy 2016, 88, 639-651. [CrossRef]

44. Salman, M.; Long, X.; Dauda, L.; Mensah, C.N.; Muhammad, S. Different impacts of export and import on carbon emissions across 7 ASEAN countries: A panel quantile regression approach. Sci. Total Environ. 2019, 686, 1019-1029. [CrossRef] [PubMed]

45. Sherwood, B.; Wang, L. Partially linear additive quantile regression in ultra-high dimension. Ann. Stat. 2016, 44, 288-317. [CrossRef]

46. Jayaraman, S.; Milbourn, T.T. The Role of Stock Liquidity in Executive Compensation. Account. Rev. 2012, 87, 537-563. [CrossRef]

(C) 2020 by the authors. Licensee MDPI, Basel, Switzerland. This article is an open access article distributed under the terms and conditions of the Creative Commons Attribution (CC BY) license (http://creativecommons.org/licenses/by/4.0/). 